\title{
ESTILO Y FORMA POÉTICA EN UNAMUNO
}

\author{
Manuel Romero Luque
}

Don Miguel de Unamuno pertenece, con toda seguridad, al grupo de escritores más representativos de las letras hispanas en el siglo XX. A su incontrovertible variedad expresiva, que le lleva a experimentar con los diferentes géneros literarios, y a un reconocimiento generalizado como novelista y autor de agudos ensayos se une también en los últimos años la estima de su obra lírica. Sin embargo, la constatación de este hecho no debe permitir que pase desapercibida su continuada reflexión acerca de distintas cuestiones relativas al proceso de la creación literaria y sobre los medios al alcance del poeta para conseguir su objetivo artístico. Así, aunque Unamuno, tal vez por esa prevención de que siempre hizo gala contra filólogos y críticos -a pesar de que él mismo ejerciera ambas actividades-, no fue partidario de reunir esos pensamientos referidos a su teoría literaria en un tratado uniforme que admitiera la denominación clásica de Poética, sí pueden espigarse a lo largo de toda su producción, en verso o en prosa, numerosos testimonios de esta preocupación por sacar a la luz los entresijos e inquietudes que acucian al poeta cuando se dispone a escribir y las premisas desde las que parte para la elaboración de su obra. En este sentido, el objeto del presente trabajo es la aproximación a dos aspectos de indudable importancia en la visión de la literatura que ofrece el catedrático salmantino, a saber: el análisis que presenta del concepto de estilo y su diferenciación de lo que entiende por forma poética.

Para el estudio de este problema existe un material de enorme valor que debe tomarse como obligado punto de partida. Se trata del conjunto de treinta y un artículos que, bajo la denominación genérica de Alrededor del estilo, aparecieron publicados en Los Lunes del Imparcial durante los meses de abril a noviembre del año 1924, año de su deportación a la isla de Fuerteventura y de su posterior marcha a París, desde donde continuaría su colaboración con el periódico madrileño ${ }^{1}$. En ellos se observa, desde un primer momento, cómo la noción de estilo se constituye en el rasgo fundamental del quehacer literario y queda lejos de presentarse en una mera definición, más o menos concisa, que la ponga solamente en relación con los rasgos expresivos utilizados por un autor. Es decir, don Miguel dota a este concepto de una mayor amplitud y de un más rico contenido teórico, de

\footnotetext{
${ }^{1}$ Las citas de esta obra se harán siempre de acuerdo con la siguiente edición: UNAMUNO, Miguel de: Alrededor del estilo, introducción, edición y notas de Laureano Robles, Salamanca, Ediciones de la Universidad de Salamanca, 1998. En adelante, se emplearán las siglas $A D E$ y, a continuación, se indicará la página correspondiente.
} 
manera que sólo a partir de este planteamiento tiene justificación una posterior referencia a los elementos retóricos y poéticos concretos que pueden aparecer en una producción literaria determinada. En Alrededor del estilo, Unamuno se detiene en distintos aspectos sobre los cuales ya había mostrado su interés con anterioridad, pero que, hasta entonces, sólo habían recibido un tratamiento disperso a lo largo de su producción ${ }^{2}$ y que ahora se dispone a estudiar continuadamente. De este modo, aunque el propio catedrático salmantino, con su singular desapego a las inquisiciones filológicas y a cualquier demostración de valor erudito, advierta al frente de los mismos que no pretende escribir ningún tratado sistemático ${ }^{3}$, enseguida se observa el esfuerzo que realiza por profundizar en todos aquellos factores que inciden sobre el objeto de análisis y cuyo resultado es, sin duda, encomiable tanto por lo exhaustivo de su intento como por la diversidad de puntos de vista desde los que aborda el problema.En primer lugar, el estilo es para Unamuno el rasgo definitorio de la personalidad del escritor, por lo que quienes carecen de ésta no pueden alcanzar en sus obras esa cualidad caracterizadora de la labor del poeta -en su sentido etimológico- y, por tanto, no lograrán verdaderamente la calificación de creador literario ${ }^{4}$. En la misma dirección apunta cuando afirma que "no hay estilo bueno ni malo, sino tenerlo o no tenerlo" ( $A D E, 38) \mathrm{y}$, en este punto, don Miguel viene a suscribir lo que será una constante de la poética de principios de siglo, la del culto al individuo y la defensa de su identidad, herencia del Romanticismo europeo que no pudo cumplirse plenamente en la literatura de lengua española y que los poetas de comienzos de siglo reivindican de nuevo ${ }^{5}$. Debe recordarse al respecto que Rubén Darío, el más significativo de aquellos escritores, proclamó también, en total coincidencia con el autor vasco, esta sentencia: "Sé tú mismo: esa es la regla"6. Para Unamuno, no cabe hablar de estilo aprendido o de escuela, porque, en su opinión, al hacerlo depender directamente de la personalidad, se trata de una cualidad ingénita del individuo. El único problema radica en saber descubrirlo dentro de sí: "Y es que el estilo no se hace. Se nace con él o no se nace. Lo que ocurre es que a las veces tarda uno en encontrar su estilo. O sea, que tarda en encontrarse a sí mismo, en descubrir su propia personalidad" $(A D E, 39)$. Al auténtico poeta le basta, en definitiva, con mostrarse tal

\footnotetext{
${ }^{2}$ Véanse al respecto los que, publicados entre 1892 y 1924, figuran en el apartado titulado "A propósito del estilo" en UNAMUNO, Miguel de: Obras completas, introducción, bibliografía y notas de Manuel García Blanco, Madrid, Escélicer, 1966-1970, 8 vols., tomo VII, págs. 823-882. A partir de aquí las citas referidas a esta obra se indicarán entre paréntesis con las siglas $O C$, seguidas del volumen y páginas correspondientes.

3 “'Los artículos que componen esta colección no son propiamente ensayos críticos ni pretende el autor que lo sean. Tan sólo lo que el título de ella dice [Alrededor del estilo. Notas de un lector por Miguel de Unamuno]. En rigor un pretexto para ir el autor entretejiendo sus propias ideas con las que le dan aquellos otros escritores a que lee" $(A D E, 31)$.

${ }^{4} A D E, 35$.

${ }^{5}$ Cfr. ROMERO LUQUE, Manuel: Las ideas poéticas de Manuel Machado, Sevilla, Diputación Provincial de Sevilla, 1992, págs. 49-53 y 143-146.

${ }^{6}$ DARÍO, Rubén: "Los colores del estandarte" en R. Gullón (ed.): El modernismo visto por los modernistas, Ed. Labor, Barcelona, 1980, pág. 55.
} 
cual es, pues aquello que persigue está ya en él por naturaleza y lo hace original y único ${ }^{7}$. No obstante, para conseguirlo no tiene por qué renunciar por completo a servirse del camino que otros autores marcaron previamente; pero tampoco debe detenerse hasta encontrar ese manantial propio con que cuenta todo auténtico creador ${ }^{8}$. El autor del Cancionero lo dejó anotado en una de sus breves composiciones:

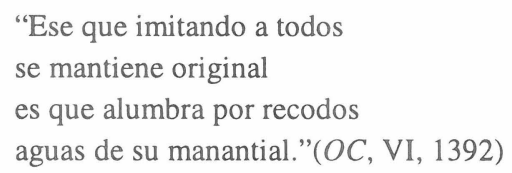

Don Miguel, en consonancia con lo expuesto, establece una precisa distinción entre el valor absoluto que otorga a este elemento poético de primera magnitud y lo que designa como estilismo. Este último término señala para el profesor salmantino, al igual que todos los "ismos", algo rígido o muerto y, en consecuencia, los que siguen cualquier modelo no pueden ser verdaderos poetas. En todo caso, serán literatos, estilistas, es decir, aquéllos que sustituyen el estilo por la manera, lo propio por lo imitado, la originalidad por la escuela. El estilista es, a lo sumo, un imitador, mientras que poeta es el que sigue inexorablemente la primera de las reglas que Unamuno puso al frente de su "Credo poético" en 1907: "Piensa el sentimiento, siente el pensamiento" (OC, VI, 168), como años más tarde reafirmaría con total contundencia: "El estilista es, pues, un literato -otras veces un sabio-, mientras que el hombre que escribe con estilo es un poeta, es un hombre que sabe y siente -siente apasionadamente- lo que sabe y sabe lo que siente" ( $A D E, 47)$. Por este motivo, el autor vasco, que en numerosas ocasiones dejó constancia de que no quería ser considerado un sabio o un hombre de letras sino todo un poeta, supo valorar las palabras que le dedicó Rubén Darío en un artículo de $1909^{9}$, donde advertía el genial nicaragüense la vigorosa y genuina orientación aportada por la obra lírica unamuniana: "La originalidad de este hombre, dicen las gentes, está en decir todo lo contrario de lo que dicen los demás, en dar la vuelta como un guante a las ideas usuales" ( $O C$, VI, 554). Pero debe hacerse hincapié en que esta característica no supone en absoluto una mera extravagancia o pose artística, sino

\footnotetext{
${ }^{7}$ Coincide también en este aspecto con otro de sus contemporáneos al que se refirió en diversos escritos, Manuel Machado. El autor sevillano cuando, a una edad avanzada, pasa revista a su vida -en un diálogo fingido entre el joven que fue y el anciano en que se ha convertido- destaca precisamente cómo empezó a reconocerse poeta en el momento en que dejó de seguir los hallazgos de los estilos ajenos y descubrió su propia voz lírica que estaba encerrada, desde el principio, dentro de sí mismo: "Pasé muchos años buscándome sin hallarme. Buscándome a través de clásicos y de románticos, y, ya casi en la madurez [...] me encontré un día, en París, con el poeta más español y más andaluz a un tiempo. Era yo mismo" (MACHADO, Manuel: "Manuel Machado habla de economía, amor y arte con Manolo Machado", La estafeta literaria, n² 14, Madrid, 10 de diciembre de 1944).

${ }^{8}$ Unamuno dirá expresamente: "Cierto que uno encuentra su estilo a través de los de los demás, que imitando se llega a ser original" $(A D E, 46)$.

${ }^{9}$ Dicho artículo, publicado originariamente en el diario La Nación de Buenos Aires bajo el título de "Unamuno, poeta”, fue utilizado por don Miguel al frente de su poemario Teresa (1924) como prólogo del mismo. Cfr. OC, VI, 553-555.
} 
que es el reflejo de su eterna preocupación por mantener su independencia ante cualquier circunstancia ${ }^{10}$.

Esta es la causa también de que uno de los rasgos formales más señalados de la poética unamuniana sea el empleo de la paradoja. Pero este recurso en Unamuno no es una mera figura retórica ejecutada con el único fin de sorprender al lector o para mostrar algún concepto desde un punto de vista inesperado. Antes al contrario, don Miguel se vale de ella como medio de reflexión profunda ${ }^{11}$, de manera que, rompiendo los tópicos conceptuales y formales de sus lectores, se dirige a ellos apelándolos directamente y hace que cada uno de los destinatarios de sus escritos pueda rehuir los esquemas mostrencos de su pensamiento y de su sentimiento para afrontar una nueva realidad intelectual y expresiva. Así pues, Unamuno procura desconcertar al lector para sacarlo de su papel pasivo y convertirlo en sujeto activo de la comunicación literaria. El poeta no puede decir al receptor de su obra lo mismo que éste ya conoce de antemano. Ha de transmitirle no sólo lo que piensa y siente, sino que, sobre todo, ha de hacerle pensar y sentir con él, aunque el lector no participe necesariamente de la opinión expuesta por el creador. De este modo, Unamuno se vale de esa presencia in mente del lector para su propia labor creativa, haciéndolo participante expreso en numerosos poemas, al igual que en muchos de los prólogos o epílogos de sus libros. El catedrático salmantino quiere mover y conmover a sus lectores. Por este motivo, Unamuno muestra su aversión hacia quienes leen sin oír lo que leen -ya sea por erudición o por vanidad- y hacia aquellos otros, a quienes llama "lectores pedagógicos", que sólo están interesados por aprender a escribir, pero ante los cuales él no desea en absoluto ejercer como profesor. Contra todos lanza sus paradojas y, especialmente, contra estos últimos para ahuyentarlos cuanto antes de sus escritos que quieren ser palabra viva y no letra muerta ${ }^{12}$.

Numerosos ejemplos de gran calidad y belleza literaria pueden aducirse sobre este particular. Baste con señalar el conocido y categórico final de su "Credo poético":

\footnotetext{
${ }^{10}$ En el "Prólogo" que Unamuno escribió en 1928, desde su destierro en Hendaya, para una frustrada edición de su Cancionero defiende precisamente esa necesidad siempre sentida de defender en todos los órdenes de la vida su particular identidad: "Sí, lo que sentimos como espíritu de independencia y llamamos así, es el sentimiento de nuestra identidad; ser independiente es ser idéntico, es ser igual a sí mismo, es ser uno mismo, es ser persona continua. Y como la infinitud no es más que continuidad -lo infinito es lo continuo, lo concreto- la persona continua es infinita e inconmensurable. Y por conservar y continuar, que es acrecer, mi identidad personal, mi personalidad idéntica, por ser yo mismo, independiente, he tenido que renunciar a volver a mi patria mientras en ella se persiga, a nombre de una fantástica realidad la íntima personalidad de cada uno. Yo quiero seguir siendo yo para que los demás españoles sigan siendo ellos y vuelvan a serlo los que lo han dejado de ser. Independencia es identidad [...]". (OC, VI, 946-947).

${ }^{11}$ Cfr. CASTRO CASTRO, Antonio: "La paradoja unamuniana. El modo más vivo y más eficaz de transmitir la verdad a los torpes”, Cuadernos de la Cátedra Miguel de Unamuno, Salamanca, 1968, XVIII, págs 71-84.

${ }^{12}$ Sobre esta esencia de la paradoja unamuniana afirma el profesor Antonio Castro: "Labor destructiva, labor de alejar a los lectores no suyos, y labor constructiva de buscar a los lectores propios, se ha logrado con la ayuda de la paradoja. De esa paradoja que desconcierta e irrita a los lectores no suyos; de esa paradoja que ahuyenta al lector no suyo, o lo convierte por un cambio de meollo, en persona nueva. La paradoja destruye. Esa paradoja antitópica o antierudita o antiprogresista: la destructora. Ésa que necesita el lector corriente para dejar de ser mero lector. Y la paradoja tiene en Unamuno la fecundidad de iluminar lo oscuro o de oscurecer lo claro" (Ibídem, pág. 83).
} 
"esculpamos, pues, la niebla" (OC, VI, 169) $)^{13}$ o cuando en otro de sus más conocidos poemas, "El buitre de Prometeo", recurre a la fuerza del mismo elemento retórico en diversos momentos de la composición para realzar la situación trágica que allí se describe: "dame un lento dolor, sordo, apacible; / dame un dolor de vida pensamiento" (OC, VI, 235). A veces, es incluso el recurso que sostiene la estructura general de todo un poema como ocurre en "La oración del ateo":
"Oye mi ruego Tú, Dios que no existes, y en tu nada recoje estas mis quejas,
Tú que a los pobres hombres nunca dejas sin consuelo de engaño. No resistes
a nuestro ruego y nuestro anhelo vistes.
Cuando Tú de mi mente más te alejas
más recuerdo las plácidas consejas,
Con que mi ama endulzóme noches tristes.
¡Qué grande eres, mi Dios! Eres tan grande que no eres sino Idea; es muy angosta la realidad por mucho que se espande
para abarcarte. Sufro yo a tu costa,
Dios no existente, pues si Tú existieras
existiría yo también de veras." (OC, VI, 359)

Valga esta breve referencia a la fuerza expresiva de la paradoja como una primera aproximación para ejemplificar la diferencia entre estilo, fuerza generadora de la creación literaria y objetivo prioritario de todo escritor, y forma poética, resultado concreto de la elección y disposición de las palabras. Así pues, el estilo no puede quedar reducido, en ningún caso, a la consideración de las palabras que el poeta emplea ${ }^{14}$. Aquél vivifica a éstas, haciendo posible que el poeta ahonde en el lenguaje con el fin de resucitarlo, de hacerlo vivo de continuo. Para esta función nada resulta más adecuado, en opinión de Unamuno, que bucear en la propia lengua a la búsqueda de metáforas. Por ello, nos dirá: "Y es para lo mejor que sirve estarle hurgando y escarbando las entrañas a un lenguaje: para sacar metáforas y resucitar así a las palabras. Que sólo son vivas, que sólo son poéticas, que sólo son evocadoras, cuando nos muestran sus metáforas" ( $A D E, 65)$. El autor del Cancionero viene a incidir de nuevo en este hecho fundamental de su poética que consiste en valorar los rasgos formales sólo en tanto que éstos contribuyan eficazmente a la consecución de un estilo propio. Numerosos testimonios podrían traerse también a colación

\footnotetext{
${ }^{13}$ Este verso dio lugar al apelativo dariano de "escultor de la niebla" referido al poeta vasco (OC, VI, 169).

${ }^{14}$ En expresión del propio don Miguel, las palabras no son sino "el cadáver de la expresión” y sólo empiezan a ser cuerpo cuando encuentran la fuerza inspiradora del estilo que es su "alma" $(A D E, 61)$.
} 
del ejercicio práctico que suponen sus versos con respecto a la teoría expresada en la última cita. En el poema "Para después de mi muerte" se refiere a su obra lírica, que perdurará más allá de su autor, con estos versos:

$$
\begin{aligned}
& \text { "¡Cuando yo ya no sea, } \\
& \text { serás tú canto mío! } \\
& \text { ¡Tú, voz atada a tinta, } \\
& \text { aire encarnado en tierra, } \\
& \text { doble milagro, } \\
& \text { portento sin igual de la palabra, } \\
& \text { portento de la letra, } \\
& \text { tú nos abrumas!" (OC, VI, 173) }
\end{aligned}
$$

En los versos anteriores don Miguel se dirige directamente a su misma poesía y observa cómo ese canto que ha producido y que es, en primera instancia, pronunciado por la voz única de su creador debe hacerse palabra -palabra escrita-. El sonido queda entonces transmutado en la sustancia negra con la que se trazan los signos sobre el papel y, en esta nueva forma, puede sostener por más tiempo tanto el pensamiento como el sentimiento de su autor. Unamuno ha buceado en el lenguaje y los vocablos habituales del idioma se han cargado de fuerza significativa para lograr la expresión definitiva. El poder evocador de la metáfora ha dado lugar a esos sintagmas hermosamente originales para referirse al proceso de transmisión de la poesía -"voz atada a tinta", "aire encarnado en tierra"- y la forma poética se presenta siempre como resultado de la indagación en la lengua y fruto del estilo personal del autor.

El autor vasco no cree, pues, en el estilo como consecuencia final de la elaboración del poema. Antes al contrario, Unamuno lo concibe como causa que origina el pensamiento, elemento éste sin el cual, de acuerdo con su particular visión, resulta imposible concebir la poesía $^{15}$. El poeta se comporta como Dios en el Génesis y el poder creador se vincula a la obra, siendo precisamente ésta -la consecuencia efectiva de su actividad- la que lo constituye en hacedor, de modo que el resultado artístico es, a la vez, origen y manifestación de su poder demiúrgico: "Llamamos la Creación al conjunto de lo creado [...]. Y es porque la Creación crea, la creación crea a su Creador. O sea que el Creador se crea creando. Creando y creándose" $(A D E, 66)$. Por esta razón, el poeta puede dirigirse a Dios en un salmo que es, a la vez, plegaria del hombre que desea la eternidad y, al mismo tiempo, recordatorio a la divinidad de que necesita de su criatura para una existencia plena:

"¡Oh, Señor, tú que sufres del mundo

sujeto a tu obra,

es tu mal nuestro mal más profundo

y nuestra zozobra!

$[\ldots]$

\footnotetext{
15 "Porque es el estilo el que crea pensamiento, y el que carece de estilo no piensa" ( $A D E, 66)$.
} 
Si has de ser, ¡oh, Dios mío!, un Dios vivo

y no idea pura,

en tu obra te rinde cautivo

de tu criatura.

$\mathrm{Al}$ crear, Creador, quedas preso

de tu creación,

más así te liberas del peso

de tu corazón." (OC, VI, 222-223)

Como consecuencia de lo expuesto, la radical individualidad del estilo hace que resulte imposible una preceptiva que recoja las normas o las características comunes que puedan precisarlo de una forma sistemática. En esta línea, Unamuno se pronuncia en favor de una definición biográfica, o por mejor decir, autobiográfica del estilo, pues éste expresa en todo escritor, y no sólo en el poeta lírico, a la persona que lo emplea y es testimonio fidedigno de la misma ${ }^{17}$. Sin embargo, ese carácter individual al que se acaba de hacer referencia necesita, como agudamente plantea el profesor salmantino, de una importante matización. Se trata de analizar el papel que desarrolla el elemento básico sobre el que se constituye toda expresión por personal que ésta sea: el lenguaje. Esto es, si el estilo es el principio caracterizador de cada autor, el lenguaje se constituye en elemento previo a cualquier configuración particular y sirve, a su vez, como elemento definidor de la nación, en tanto conjunto de hablantes que emplean un mismo medio de expresión. Pero el lenguaje, como el estilo, es algo vivo y en constante elaboración, sólo que arrastra también la memoria expresiva de cuantos lo utilizaron y utilizan.

La exposición de este planteamiento la realiza don Miguel al hilo de una frase de Buffon $^{18}$ que encuentra al leer la introducción de un libro de Salvador de Madariaga,

\footnotetext{
${ }^{16}$ Es más, el poeta no es sólo, como todos los hombres, creación hecha por Dios a su imagen y semejanza, sino que, porque aspira a crear su propia obra y se preocupa de ella como la divinidad cristiana de sus criaturas, se comporta a la manera del sumo Hacedor y, a la recíproca, Éste puede ser también considerado como Poeta del universo. Por esta razón, cuando el autor del Cancionero examina sus versos del exilio, puede decir:

"Pues que soy, Padre, tu imagen
y a tu semejanza he visto
que es buena esta pura obrilla
que de mi pecho ha salido.

$[\ldots]$

$\mathrm{Y}$ al ser buena te la vuelvo por ser tuya, Señor mío, Creador de los poetas,

Poeta del Infinito." (OC, VI, 953)

${ }^{17} \mathrm{Cfr} . A D E, 69-70$.

${ }^{18}$ Georges-Louis Leclerc, conde de Buffon (1707-1788) científico y escritor francés, autor, entre otras obras, del Discurso sobre el estilo (1753) en donde actualiza las normas de la poética clásica.
} 
titulado Semblanzas literarias contemporáneas ${ }^{19}$, en el que el autor vasco es uno de los escritores allí analizados. La frase aludida y que desencadena su pensamiento es ésta: "El estilo es el hombre". Unamuno, tras su lectura, se manifiesta en estos términos: "Lo mismo pudo haber dicho: «El lenguaje es la nación». El lenguaje es el material del estilo literario, pero no como el mármol, o el bronce es el material de la escultura, porque el lenguaje es ya algo orgánico y vivo [...]. ¿Diremos, pues, que el lenguaje es el contenido y el estilo el continente? Pero el lenguaje a su vez es continente, es forma, es estilo. Y no sería paradójico sostener que el estilo de un escritor es el contenido de sus escritos, y el lenguaje de que tienen que servirse su continente. [...] El lenguaje tiene su estilo; el lenguaje es estilo, puesto que es un pueblo, y un pueblo es un hombre" ( $A D E, 73)$, a lo que sigue una reflexión sobre el carácter del individuo como condensación y representación de la historia del pueblo al que dicho individuo pertenece ${ }^{20}$.

En definitiva, Unamuno lo que quiere es alejar el concepto de estilo de una mera consideración "formalista", en el sentido de que el texto literario pueda ser entendido como una suma de tropos o figuras retóricas que "adornan" los escritos de un autor. Para él, por tanto, el estilo se define principalmente como resultado de ese proceso creativo que exige la amalgama del pensamiento y el sentimiento, pilares de su poética destinados a servir de soporte al artificio. Éste es, sin duda, también necesario para el poeta, pero sólo surge con posterioridad y como reflejo de ese carácter personalista y autobiográfico con el que el poeta vasco concibe el estilo. De esta forma, puede llegar a la conclusión que anteriormente hemos citado: "el estilo de un escritor es el contenido de sus escritos", en tanto que ese contenido no es sólo argumento, fábula, sino plasmación de una manera de observar el mundo -interior o exterior- del creador literario, lo absolutamente original y propio. Con

\footnotetext{
${ }^{19}$ Barcelona, Ed. Cervantes, 1924.

20 "Porque todo un hombre, un ciudadano es todo su pueblo, es la condensación de la ciudad toda. Y el hombre que es todo un hombre, que es todo un pueblo, que es todo su pueblo -del que es hijo y a la vez padre, jmisterio de trinidad-, lleva en sí las mismas antinomias y antagonías de su pueblo, lleva en sí la guerra civil, que es, si su pueblo tiene historia, si vive como pueblo, la esencia la personalidad del pueblo. Sí; la guerra civil, la antagonía íntima, es la historia de un pueblo, y la historia de un pueblo es su estilo, su personalidad. Estilo, como todo estilo, vivo, o sencillamente, como todo estilo, antagónico en sí y para sí, contradictorio" ( $A D E, 73-74)$. De ahí que, en paralelo con su teoría estilística, se puedan leer estas estrofas en el primeros de sus libros de versos:
}

"iOh, mi Bilbao! Tu vida tormentosa

la he recojido yo; tus banderizos

junto a tus mercaderes en mi alma

viven sus vértigos.

Dentro de mi corazón luchan dos bandos,

y dentro de él me roe la congoja

de no saber donde hallará mañana

su pan mi espíritu.

Vives en mí, Bilbao de mis ensueños; sufres en mí, mi villa tormentosa; tú me hiciste en tu fragua de dolores y de ansias ávidas." (OC, VI, 203) 
ello, puede completar además esta visión del problema dejando que sea el lenguaje, la lengua de todos los hablantes, quien ocupe preferentemente el lugar del continente, entendido como medio expresivo general de todos los miembros de la comunidad, que le viene dado al poeta, y sobre el que actúa la personalidad de cada autor para extraer de ese acervo patrimonial los más variados registros artísticos.

Según este razonamiento que don Miguel va exponiendo a lo largo de su colección de artículos dedicados a este problema teórico-literario, la dificultad estriba entonces en la capacidad de todo escritor para conocer y desarrollar su estilo propio y único. Esto le lleva a unir el concepto de estilo a otro principio fundamental para el establecimiento de su poética cual es la noción de ritmo. Lo hará a partir de una pregunta: "Pero, ¿ conoce uno su propio estilo? O sea: ¿Se conoce uno a sí mismo? He aquí un problema. Y tanto más difícil de solución cuanto uno es más pueblo, cuantas más antagonías y contradicciones encierra en sí, cuantas más discordancias concordantes. Porque esto es el ritmo, o sea el estilo, la concordancia de las discordancias" ( $A D E, 79)$.

De todos es sabido que el ritmo es un elemento esencial en el lenguaje literario y puede definirse como el resultado de la distribución de elementos tales como la repetición del número de sílabas, las pausas, la situación de los acentos métricos o la rima si se trata de un texto en verso, pero que también atiende a la estructuración de la frase, la recurrencia de los distintos elementos lingüísticos o la distribución acentual que ofrecen los textos en prosa. En definitiva, la identificación del ritmo está relacionada con la reiteración de estructuras equivalentes $^{21}$. Pero, con mayor amplitud podríamos referirnos a él como la adecuada combinación de todos los componentes temáticos o formales de un poema o texto en prosa para ofrecer un conjunto armónico y perfectamente trabado ${ }^{22}$. En todo caso, los críticos y teóricos de la literatura están de acuerdo en subrayar, como hace Kurt Spang, que "el ritmo es el centro, el motor y el corazón de la lírica, aunque no carece de dificultad una sólida definición del ritmo en la lírica"23 y ahí radica el problema de su análisis.

De la importancia del mismo en la visión de la lírica de Unamuno dan testimonio las numerosas referencias que diseminó a lo largo de su producción poética. Por ejemplo, al abrir su primer libro de versos se encuentra el poema titulado “iId con Dios!”, en el que,

${ }^{21}$ Véanse DOMÍNGUEZ CAPARRÓS, José: Diccionario de métrica española, Madrid, Alianza, 1999; REYZÁBAL, María Victoria: Diccionario de términos literarios, Madrid, Acento, 1998, 2 vols.; PARAÍSO DE LEAL, Isabel: Teoría del ritmo de la prosa, Barcelona, Planeta, 1976; y TORRE, Esteban: El ritmo del verso (Estudios sobre el cómputo silábico y la distribución acentual, a la luz de la Métrica Comparada, en el verso español moderno), Murcia, Servicio de Publicaciones de la universidad, 1999.

${ }^{22}$ En esta dirección, el profesor Núñez Ramos lo ha definido en los siguientes términos: "El ritmo [...] es la expresión misma del efecto estético del poema, pues en el ritmo se produce no ya la fusión de todos los planos y niveles del objeto poético, sino la incorporación de éste en su globalidad en el organismo mismo del observador y la supresión de la separación entre sujeto y objeto; todavía más, el ritmo es la forma de existencia estética del poema, pues sólo en su ejecución gobernada por las exigencias del ritmo alcanza consistencia y concreción, se vuelve sensible, el material abstracto del lenguaje que lo sustenta" (NÚÑEZ RAMOS, Rafael: La poesía, Madrid, Síntesis, 1992, pág. 183).

${ }^{23}$ SPANG, Kurt: Géneros literarios, Madrid, Síntesis, 1996, pág. 61. 
con un doble sentido, hace mención tanto al saludo de despedida que el poeta dirige a sus composiciones, al iniciar con éstas su andadura en el campo de la lírica, como a una orden de envío que da a sus propios versos para que respondan por él ante Dios de su labor como poeta. En él se hace ya alusión a ese poder constitutivo del ritmo como fuerza engendradora de toda creación literaria; de manera que sólo las composiciones que han conseguido ese efecto eurítmico aparecen como obras logradas, pero son muchos más los intentos fallidos que desaparecen sin que podamos ver sus huellas:

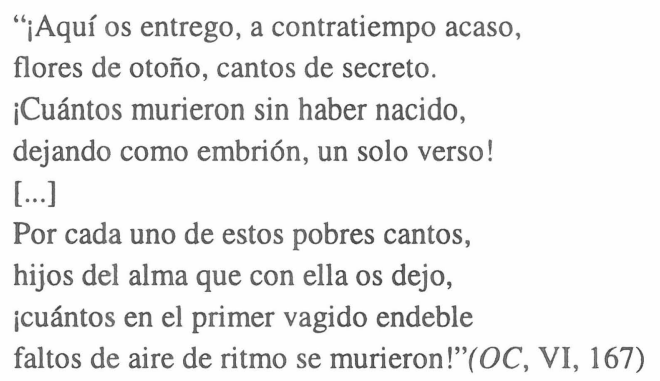

Es la capacidad de encontrar el pulso adecuado en la expresión y el contenido lo que diferencia por completo al poeta de los demás hombres y ello se fundamenta, en primera instancia, en una actividad de carácter espiritual. En el prólogo a Teresa, declaró don Miguel: "Un poeta es el que desnuda con el lenguaje rítmico de su alma. El ritmo, además, le sirve como el bieldo de aventar en la era para apurar su pensamiento, separando, a la brisa del cielo soleado, el grano de la paja" $\left(O C\right.$, VI, 577) ${ }^{24}$. En efecto, el ritmo no es un mero artificio estético, sino que sirve al poeta para acendrar pensamiento y sentimiento y ofrecerlos depurados en el poema. Es lo que en verdad diferencia la retórica de la poética, entendidas como formalización literaria y fundamento de la poesía respectivamente, o sea, la una engalana mientras que la otra señala la esencia de la creación poética. En palabras de Unamuno: "Sabido es que la retórica sirve para vestir y revestir, acaso para disfrazar, el pensamiento y el sentimiento, cuando los hay y que la poética sirve para desnudarlo" $(O C$, VI, 577) ${ }^{25}$.

\footnotetext{
${ }^{24}$ Esta misma declaración se incluye entre las breves notas de poética que preceden la selección de sus poesías en la conocida antología de Gerardo Diego (Poesía española contemporánea (1901-1934), Madrid, Taurus, 1964, pág. 60).

${ }^{25}$ No se nos oculta que a esta consideración sobre poética y retórica, expuesta en el prólogo a Teresa de 1924 , se podría oponer el planteamiento que ofrece sobre ambas disciplinas en la composición número 675 de su Cancionero, fechada cinco años después, pero entonces el contexto literario ya era muy distinto y Unamuno lo que hará entonces no es sino reafirmarse de nuevo en su independencia como persona y como poeta. Dicen los versos:
} 
Más aun, se podría afirmar que toda poesía, reducida al máximo en cuanto a la caracterización de sus componentes, tiene dos elementos constitutivos básicos: ritmo y palabras. Por esta razón, cuando el poeta se dispone a crear, se encuentra en un estado en el que, antes de preguntarse a sí mismo sobre el motivo de su canto o de buscar un tema sobre el que basar el poema, debe dejarse arrastrar por el flujo de esa especie de cadencia espiritual que le invade y, a partir de ahí, comenzará la búsqueda de la palabra. Pero una palabra que aparece revestida de su valor originario y divino por el cual son creadas las cosas. En su Cancionero, pueden encontrarse versos bien definitorios de esta actitud:

$$
\begin{aligned}
& \text { “A ver, qué tienes que decirte? aguarda, } \\
& \text { el ritmo mismo te traerá la idea } \\
& \text {-duerme en el seno del lenguaje mudo- } \\
& \text { busca tan sólo las palabras, ellas } \\
& \text { te crearon el alma y al creártela } \\
& \text { te hicieron creador; esto es: poeta."(OC, VI, 983) }
\end{aligned}
$$

Por otra parte, Unamuno precisa en multitud de ocasiones una diferenciación que debe ser observada. Se trata de la distinción existente entre ritmo y música, de manera que mientras aprecia y valora el primero de ambos conceptos, rechaza o minusvalora al segundo. En esta línea, es de sobra conocida una tajante afirmación de su "Credo poético": "algo que no es música es la poesía". Con la cual parece significar su declaración de guerra contra el conocido precepto verlaineano que, en el inicio del "Art poétique", declaraba: "De la musique avant toute chose, ${ }^{\text {,26 }}$, sentencia ésta que había sido seguida con devoción por la mayor parte de aquellos autores que, a finales del XIX y principios del XX, se propusieron innovar los modelos poéticos en lengua española desde ambas orillas del Atlántico. Sin embargo, no debía haber olvidado Unamuno que Darío, en sus "Palabras liminares" colocadas al frente de Prosas profanas (1896), había escrito que la música a la cual aspiraban los seguidores del maestro francés no estaba dirigida exclusivamente al oído, sino que, en muchos casos, se trataba de una armonía conceptual. Así lo hizo saber el admirado poeta nicaragüense: "¿Y la cuestión métrica? ¿Y el ritmo? Como cada palabra tiene un alma, hay en cada verso, además de la armonía verbal, una melodía ideal. La música es sólo de la idea muchas veces" 27 . No obstante, las diferencias en este punto entre don Miguel y el que fuera modelo simbolista del Parnaso hispano resultan notables. Si Verlaine proponía en su renombrado poema como patrón poético la agilidad del verso, que las palabras adquirieran una significación ambigua como una declaración velada, oscilante, llena de matices y claroscuros y, sobre todo, la persecución de una música tenue en que se diluya

$$
\begin{aligned}
& \text { y de la crítica. } \\
& \text { Líbranos de los píos } \\
& \text { y de los jipíos, danos goce impuro } \\
& \text { de afán inseguro; } \\
& \text { sálvanos, retórica." (OC, VI, 1151) }
\end{aligned}
$$

\footnotetext{
${ }^{26}$ Puede consultarse el texto original del poema y la excelente traducción del mismo ofrecida por Esteban Torre en 33 poemas simbolistas (Madrid, Visor, 1995, págs. 70-73).

${ }^{27}$ DARÍO, Rubén: Prosas profanas, Madrid, Espasa-Calpe, 1977, pág. 11.
} 
todo el poema, Unamuno, de ánimo y carácter tan distintos, le opondría versos como los siguientes:

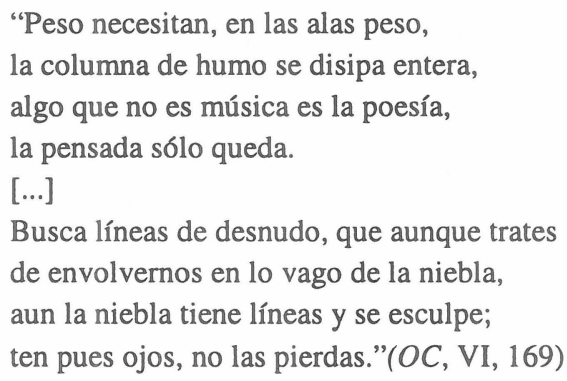

Existe en este punto un claro enfrentamiento entre ambos creadores. Mientras para el poeta francés el hilo conductor de la poesía era, como se ha dicho, la música, y ésta sin posibilidad de ceder nunca su puesto predominante ("De la musique encore y toujours"), don Miguel otorga ese valor constituyente de la poesía al ritmo, sustituyendo la imprecisión o el matiz por contornos firmes, cerrados, densos:

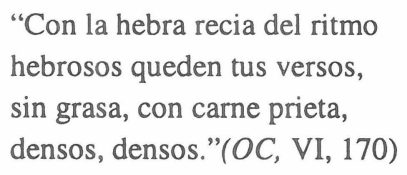

Por eso irrita tanto al autor español el desconocimiento de esta verdad axiomática de su poética que se empeñó en proclamar insistentemente, defendiéndose de una noción exclusivamente melodiosa y adormecedora del ritmo, hasta el punto de insultar a aquellos que son incapaces de comprender su postura: "Y en tanto, dejemos que los mentecatos confundan el ritmo con el compás y no reconozcan otra música que la bailable. Llevan el compás con los pies. Cuando no, con una cana de medir telas de saco" (ADE, 79). Él prefiere encontrar su ritmo, su calidad de expresión artística, aunque sea a contracorriente. Sabe que en ello radica su misión como verdadero poeta, si quiere alcanzar la perdurabilidad que siempre le obsesionó.

Lengua y personalidad conforman, pues, el estilo de todo escritor, su huella identificadora y exclusiva. Pero esto no puede lograrse sin desazones que llevan a don Miguel a plantearse la razón de ser de su tarea. En carta a Menéndez Pidal, fechada en Salamanca el 14 de mayo de 1915, se expresará con total franqueza sobre su intento por hallar un estilo propio que aúne renovación personal y dominio del lenguaje: "Esta miserable lucha por la personalidad me está tal vez perjudicando; y luego viene mi batalla con la lengua, mi esfuerzo por hacerme una, que siendo castellana sea seca, precisa, rápida, sin tejido conjuntivo, sin las lañas y corchetes y hebillas que al castellano estropean, nada oratoria, caliente y de una sintaxis que no rompa el nexo de la espontánea asociación de ideas. Hay quien cree que descuido la forma, siéndome de las cosas que cuido más, sólo 
que mi cuidado es hacérmela propia de mi fondo" 28 . Con estas palabras muestra, una vez más, ese ideal de equilibrio que persigue entre los componentes de la creación artística. A don Miguel no le sirven poéticas o preceptos ajenos ${ }^{29}$. Prefiere seguir su propio camino, siempre adelante, en una constante búsqueda que le permita la expresión lírica de sus pensados sentimientos, sin la pretensión de alcanzar una quimérica perfección absoluta.

Más aun, cualquier autor que se precie ha de renunciar a todo tipo de banderías para dedicarse, en exclusiva, a la tarea de hallar ese estilo que lo defina sea cual sea el género literario al que destine su esfuerzo creativo o, de lo contrario, sería tanto como renunciar a su propio yo. Por eso, con la habitual rotundidad con que suscribía sus principios estéticos, no dudaría en manifestar: "Las obras de un escritor que no parecen de él, que carecen de estilo, que parecen de otro, no son de nadie, no son obras. Otro es nadie" ( $A D E$, 97). Pero, dando una vuelta más de tuerca en ese razonamiento que guía su reflexión, Unamuno afirmaría que esa mismidad de cada autor, reflejada en su manera de expresarse, no es tanto producto del individuo que la persigue, cuanto elemento constituyente y moldeador de quien la emplea. En suma, dirá: "El estilo nos hace; no hacemos el estilo" $(A D E, 102)$. No se trata sólo de que la personalidad configure la particular realización de un modelo estilístico, sino que es ésta forma peculiar perseguida por cada escritor la que contribuye a definirlo con mayor precisión que ningún otro aspecto. Esta función del estilo es precisamente el motor que sirve para prolongar la existencia del poeta en cuanto hacedor de un mundo, porque, como quedó expuesto más arriba, el creador se crea a sí mismo mediante el ejercicio de su labor y en cuanto tal poeta, según el significado etimológico del término, su tarea le incluye en un proceso de autoconstrucción.

Para conseguirlo, el autor ha de trabajar en busca de la consecución de una forma poética única, pero hasta llegar a ese fin debe enfrentarse a un problema insoslayable en cualquier realización artística: el dominio del material sobre el que se elevará su proyección personal. En la literatura, el arte de la palabra, ese material no es otro que la propia lengua.

\footnotetext{
${ }^{28}$ Cit. GRANJEL, Luis S.: Retrato de Unamuno, Madrid, Ediciones Guadarrama, 1957, pág. 287.

${ }^{29}$ Debe recordarse al respecto que don Miguel, autor de tan profundas paradojas, a los preceptos, y al conjunto de ellos, es decir, la preceptiva opone los "postceptos". A ambos se refiere por extenso en las notas finales a Teresa:

"Y en cuanto a la preceptiva, hay que decir que en crítica y aún en estética, no debe uno valerse de preceptos, sino de postceptos. Y voy a explicarme.

»Precepto de praeceptus y éste del verbo praecipere -de prae, antes y capere, tomar- es lo que se toma de antemano, una regla que precede a su aplicación. Y me place inventar otro precepto crítico, el postcepto, de un supuesto verbo latino, postcipere, tomar después, que si no existió pudo haberlo inventado alguien como se inventaron postponere, postcribere, postferre, postire y algún otro. Y el postcepto sería la regla que sale de los hechos, la ley que surge de la costumbre, y no como el precepto la que pretende moldear los hechos y hacer la costumbre. Y este es el nudo de la buena crítica.

„El fin del arte es realizar belleza, o sea dar gusto a los que gocen de sus productos. Y el modo de averiguar cómo se ha de dar gusto es estudiar cómo se ha dado gusto y cómo se da gusto. Sólo cabe determinar cómo se ha de producir placer -en el caso del ritmo y la rima y la versificación al oído- estudiando cómo se ha producido y se produce ese placer. El fin de la crítica es esclarecer por qué gusta lo que gusta y no gusta lo que no gusta, y es necedad criticista preceptuar que algo no debe gustar, si gusta, o que debe gustar, si no gusta. Por algo se ha dicho que sobre gustos no hay disputa. Y bello es lo que gusta" (OC, VI, 657).
} 
Pero ésta supone, ya en principio, una determinada estructuración formal -que encierra a su vez una concreta visión del mundo- sobre la cual habrá de elaborar el poeta una segunda conformación específica ${ }^{30}$. Sin embargo, don Miguel no quiere incidir aquí en el hecho de que eso suponga una dificultad añadida, por la cual el poeta deba "inventarse" un lenguaje absolutamente desconocido. Antes al contario, el profesor salmantino subraya que el escritor no hace sino emplear la lengua de todos y con ella, explorando nuevas vías, elabora su propio código expresivo. Ahí está su mérito, no exento, claro es, de un inconveniente que suele aparecer al principio de esa aspiración por encontrar la voz original del poeta: la posibilidad de que no sea comprendido o aceptado por aquellos lectores a los cuales pretende dirigirse. En esta situación, Unamuno insiste en que el autor, antes de renunciar a su propósito, debe dar tiempo a los receptores efectivos del mensaje para que se adapten a la novedad que les presenta y puedan, pasado el primer desconcierto, acoplarse a la forma propuesta por el poeta, nunca a la inversa. Don Miguel huye de la transparencia en favor de la propia desnudez que todo estilo auténtico representa. Ello exige un esfuerzo de acercamiento por parte del receptor, que está lejos de ser concebido como mero espectador de la obra. Si Unamuno rechaza en su concepción de la lengua literaria tanto un purismo preceptista, que quita jugo y vitalidad a la lengua, como un casticismo reductor, que limite los márgenes expresivos, es precisamente para que, demostrando un pensamiento y un sentimiento propios, pueda también inculcar a sus lectores un movimiento recíproco de alerta intelectual ${ }^{31}$.

Dos conclusiones importantes se derivan de este planteamiento: de una parte, el estilo es, en definitiva, cuestión de personalidad; de otra, el lector llega a ser valorado como coautor del escrito. En cuanto al primero de los aspectos señalados, escribiría: "Pero la personalidad, que es el estilo, ni contribuye al progreso, ni progresa. [...] El que tiene estilo se expresa, se manifiesta, se revela tal cual es -o tal cual quiere ser-, y es perfecto o acabado en cada momento. Es el que es, y basta. [...] Cuando oigáis decir de uno que su estilo no es perfecto, no es acabado, estad seguros de que no es estilo" (ADE, 125) $)^{32}$. Hay, pues,

\footnotetext{
${ }^{30}$ En esta dirección, que iguala el arte de la palabra a las demás artes en cuanto al dominio que se precisa sobre la materia para lograr la forma artística, dirá: "iLa resistencia del material! La conoce el escritor, el orador, sobre todo poeta, tan bien como el escultor, el arquitecto. El lenguaje es una materia -y, por lo tanto, una forma- y resiste a otra forma. Lo mismo si el escritor hiñe o modela que si esculpe" $(A D E, 122)$.

${ }^{31}$ Acudiendo de nuevo a las propias palabras de Unamuno, podemos leer: "Pero ¿es la resistencia del material tan grande como se dice y se cree, como se dice que se cree o se cree que se dice? Ni menos. El artista hace su material; el escritor hace su lengua. La hace con palabras de todos -aunque no siempre-; pero se la hace. Y a las veces empieza apareciendo oscuro, hasta que el oyente o el lector se hace a su tono, a su estilo. Y hay oscuridades aparentes que proceden de pura claridad, de una claridad que, deslumbrando al lector, le impide ver" $(A D E, 123)$.

${ }^{32}$ Una opinión equivalente a la del profesor salmantino es la de su contemporáneo Manuel Machado, a quien en diversas ocasiones Unamuno supo valorar como poeta a pesar de las notables diferencias que pueden apreciarse entre ambos. El mayor de los Machado, en su discurso de entrada a la Academia, se pronunció al respecto con las siguientes palabras: "Es de saber que desde que yo escribo conscientemente algo de que puedo considerarme responsable para mí escribir es... no escribir. Así como otros confían inmediatamente a la cuartilla aquello que se les va ocurriendo, a reserva de corregirlo, modificarlo, perfeccionarlo luego, yo no consigno al papel sino aquello que habría de quedar en última instancia, y todas aquellas operaciones de selección y acabamiento se obran en mi interior de forma involuntaria y fatal; es decir, que voy rechazando, y dando de lado, sin querer, a todo lo que luego habría de quitar, y aduciendo cuanto tendría que poner, con que la composición queda acabada y perfecta
} 
también en esta declaración un claro exponente de perdurabilidad. El arte no progresa porque su objetivo es distinto, consiste en la persecución de lo eterno ${ }^{33}$. A ello, colabora, sin duda, el receptor, quien -de acuerdo con el segundo de los aspectos señalados anteriormente- cuando lee las obras que mantienen ese estilo único de que las dotó su autor, las vivifica y eterniza. Unamuno fue siempre consciente del importante papel del lector en la constitución de la obra artística. Por este motivo pudo escribir pasajes como el que se cita a continuación: "«iSi parece escrito hoy...!» -se exclama ante algo que tiene estilo. Y así es, porque está escrito en el momento que lo leemos, porque lo escribimos nosotros mismos al leerlo, porque lo re-creamos al re-crearnos con ello. Ya que el consumo es una forma de producción. Y no era tan absurda la paradoja de aquel lector que al preguntarle. «Y usted, ¿no escribe?», contestó: «Yo produzco consumo». Añadiendo: Escribo lo que me dan a leer». ¿O es que crees, lector, que yo no sé que estás escribiendo conmigo esto que los dos leemos?" ( $A D E, 127)$. En definitiva, uno de los problemas de la poesía es, no debe olvidarse, la existencia de lectores con la suficiente competencia lírica ${ }^{34}$. Pero, a pesar de todas las circunstancias adversas que se ofrecen al poeta, éste no puede desistir de su tarea, puesto que su labor constituye igualmente un compromiso con la sociedad ${ }^{35}$.

El autor del Cristo de Velázquez también se detuvo en analizar, siquiera fuera brevemente, el problema de la traducción en relación con el estilo. Exiliado en Francia, y necesitando publicar en periódicos y revistas del país vecino, don Miguel inicia su reflexión partiendo del lazo indisoluble que establece entre lengua y pensamiento para, desde este punto de vista, plantearnos la siguiente situación: si, por un lado, cree que sólo en su lengua materna puede verdaderamente mostrarnos ese pensamiento y sentimiento coaligados que conforman su estilo -la palpable demostración de su personalidad-; por otro, considera que,

(en el sentido latino), tanto que ya no es susceptible de retoque o corrección (por mí al menos), y no porque esté mejor o peor, sino porque no puede estar de otro modo" (MACHADO, Manuel: Unos versos, un alma y una época, Madrid, Ed. Españolas, 1940, págs. 72-73).

33 "El arte, la belleza, es eternización de la momentaneidad. "Carpe diem!" -dijo el latino-; pero lo que hay que coger al vuelo no es el día, es el instante que pasa. Y esto hace el estilo, el estilete, clava en la eternidad el vuelo de las sombras de los pájaros del cielo" $(A D E, 126)$. También puede establecerse aquí un paralelismo con los conocidos versos de Antonio Machado donde declaraba su visión de la poesía:

"Ni mármol duro y eterno,
ni música ni pintura, sino palabra en el tiempo."

(MACHADO, Antonio: Poesías completas, Madrid, Espasa-Calpe, 1980, pág. 298)

${ }^{34}$ A esta consideración apuntaba Rubén Darío, cuando en la lucha por la renovación de la lírica a principios de siglo, escribió: "No. La forma poética no está llamada a desaparecer, antes bien a extenderse, a modificarse, a seguir su desenvolvimiento en el eterno ritmo de los siglos. Podrá no haber poetas, pero siempre habrá poesía, dijo uno de los puros. Siempre habrá poesía y siempre habrá poetas. Lo que siempre faltará será la abundancia de comprendedores" (DARÍO, Rubén: "Dilucidaciones" en R. Gullón (ed.): ob. cit., pág. 59.

${ }^{35} \mathrm{El}$ testimonio de las palabras de Unamuno resulta insoslayable de nuevo: "El de escribir es el oficio, es el deber, es la obligación para con la comunidad humana, en la que vivimos, nos movemos y somos. Aunque sea luego justo que el sacerdote viva del altar. El que escribe por oficio en este su primitivo y más alto significado; el que escribe por obligación moral, por deber filial hacia la sociedad en que vive, se mueve y es, éste debe ser un hombre que escribe, y un hombre, si es hombre, tiene que tener estilo. Y si no es hombre que se calle" $(A D E, 137)$. 
al no ser sus escritos sino la exposición de las inquietudes de un hombre, a nadie puede resultarle ajeno el timbre de su voz. En esta tesitura escribió: "Cuando aquí, en Francia, me vi obligado en cierto modo -he aquí una frase hecha- a dirigirme al público, a un público francés, en francés empecé diciendo que en otras lenguas podrá, aunque sea mal, vestir mi pensamiento; pero que sólo en la mía, en la lengua española, puedo desnudarlo -como que mi pensamiento es lengua española que en mí piensa-, y luego que a ningún pueblo puede sonarle a acento extranjero el acento humano, y que con acento humano iba a hablarles" $(A D E, 117)^{36}$.

Sin embargo, Unamuno se lamenta de que la lengua francesa no se adapte con justeza a su personal expresión y ello como consecuencia de un exceso de academicismo o de haber generalizado un modelo cuya virtud principal radica en su carácter comunitario ${ }^{37}$. De ahí que el catedrático de Salamanca se cuestione abiertamente: “¿Es que la originalidad es intraductible? ¿Es que lo original en una lengua no puede pasar a otra?” (ADE, 119) y, a continuación, partiendo de la etimología del vocablo original, matiza: "Y original es lo naciente o surgiente. Y lo que nace luego se transmite, se le hace vivir, se le convierte en tradición. Pero en tradición viva. Y tradición es algo así como traducción, pues el tradere, entregar o transmitir, es un traducir. Cabiendo originalidad en la traducción [...]. Hay, sin duda, traducciones originalísimas; las hay que tiene el valor de una creación primitiva, que tienen estilo. Porque hay quien piensa y siente en una lengua lo que otro pensó y sintió en otra" ( $A D E, 119)$. Don Miguel concibe, pues, la traducción como actividad creativa y no como mera técnica ${ }^{38}$. A este propósito resultan equivalentes las cualidades relacionadas con el estilo, ya que para traducir es necesario, al igual que para toda actividad poética, la vinculación de pensamiento y sentimiento que, en este caso concreto, conducirá finalmente a la utilización de un molde lingüístico distinto al primitivo, pero basado en unos mismos presupuestos teóricos y de los que no puede quedar ausente el factor de la personalidad, característica inexcusable de toda auténtica producción artística.

Como ha podido comprobarse a lo largo de estas páginas, este profesor y poeta hace girar el conjunto de su teoría literaria en torno al tan citado verso inicial de su "Credo poético", donde ese "Piensa el sentimiento, siente el pensamiento" se convierte en el eje del proceso de creación poética y, a la vez, actúa de parámetro para enjuiciar los resultados

\footnotetext{
${ }^{36}$ Más adelante, concluye esta reflexión afirmando que lo individual es, a la vez, lo más universal: "Lo que yo quería decirles al hablarles de mi acento humano, de mi acento universal, era mi acento individualmente personal o personalmente individual-, mi estilo de decir y de pronunciar y de acentuar. Porque lo individualmente personal es lo más humano que hay. Lo individual es el colmo de lo comunal" $(A D E, 117)$.

37 “Porque hay aquí, en Francia, más que en otra parte, no ya una gramática, una retórica nacional, oficial, realista tal vez, imperialista a las veces, republicana acaso, una manera democrática. ¿Estilo? Estilo, no, sino negación de estilo. Y así, cuando se oye decir: "aquí casi todos escriben bien», hay que traducir que nadie escribe o que escribe la masa. ¿Escriben? No, está escrito. Componen al modo de un tipógrafo" $(A D E, 118)$.

${ }^{38}$ Sobre los problemas que plantea la traducción literaria, en general, y la traducción del verso, en particular, consúltese: TORRE, Esteban: Teoría de la traducción literaria, Madrid, Síntesis, 1994. En la misma dirección apuntada por Unamuno, el profesor Torre considera en la obra citada que "la traducción poética pertenecería, en fin de cuentas, al dominio del arte, y no sería más que una forma de creación literaria, que consistiría en recrear en otra lengua una obra ya existente en una lengua dada" (pág. 160).
} 
obtenidos. Por ello, al concluir esta serie de estudios dedicados al estilo, no puede sino volver a hacer referencia a este planteamiento para explicarnos qué entiende, en definitiva, por este concepto. Lo hace, tras una negativa inicial seguida de una generalización ${ }^{39}$, estableciendo dos principios fundamentales: la defensa de que no se trata de una cuestión exclusivamente formal, sino que abarca esa dualidad básica de su poética que aúna sentir y pensar como fruto de la personalidad de cada uno ${ }^{40}$, y la equiparación que establece entre ritmo y estilo ${ }^{41}$.

Distinta situación se plantea a la hora de examinar su visión de la forma poética. Unamuno no entiende este concepto como técnica o habilidad para el manejo de elementos retóricos o prosódicos de los que sí hicieron gala otros de sus contemporáneos. Don Miguel se muestra repetidamente consciente del valor que la forma alcanza en toda expresión artística, sólo que, como ha señalado con acierto la profesora Imízcoz Beúnza ${ }^{42}$, habría que hacer una distinción entre forma externa e interna, siendo esta última su principal preocupación. Desde esta perspectiva, la forma interna, que podría denominarse también en expresión de Juan Ramón Jiménez- como el fondo de la forma ${ }^{43}$, se concibe como la actitud del poeta mediante la cual se van intuyendo y seleccionando las construcciones lingüísticas que explicitarán el tema. Es esa necesidad que el poeta siente de comunicar, de expresar su sentimiento y su pensamiento, unida al trabajo interior que supone el hallazgo de la expresión precisa, perfecta. El poeta busca, pues, desnudar ese pensamiento y sentimiento únicos en una forma también exclusiva para la cual no valen consejos de escuela.

Sin embargo, esto no puede hacernos olvidar la existencia de esa forma externa a la que el poeta ha de llegar finalmente para conseguir el resultado del poema. Aquí deben tenerse en cuenta las influencias que sobre su obra ejercieron autores como Quevedo, Shakespeare y los poetas metafísicos ingleses, Bécquer o Carducci, la preferencia por los metros de ritmo endecasilábico que trocaría al final de su vida por una mayor aceptación y empleo del

\footnotetext{
39 “El estilo no es, pues, el tipo; no es algo clasificable. Ni es, en rigor, definible. No cabe definir el estilo. [...] El estilo creo que podemos decir ya que es lo puramente cualitativo, que es lo que los artistas llaman la calidad de la obra de arte. El estilo es la calidad de la expresión artística" $(A D E, 153)$.

40 "En el arte de hablar y en el de escribir llamamos estilo a la manera personal de pensar -repito que sentir es pensar-, llevando las ideas que nos son dadas hacia la derecha o hacia la izquierda, o hacia arriba o hacia abajo, o hacia delante o hacia detrás, y llevándolas con tal o cual rapidez, en línea recta o en zigzagueos rectilíneos, o en esta o la otra línea curva y con tal o cual curvatura" $(A D E, 155)$.

41 “«¡Y esto -dirá el lector avisado- es el ritmo!» ¡Palabra que así es! ¡Eso es, lector amigo, eso, el ritmo! El ritmo es la raíz del estilo. Y cada cual tiene su ritmo, como cada cual tiene su estilo, háyalo o no encontrado. [...] Como que al estilo, al punzón le lleva la mano, ya sosegada, ya febril, ya temblorosa, y a la mano la lleva el corazón, y al corazón el pensamiento, y al pensamiento el hombre. Y en el estilo va el ritmo del hombre" $(A D E, 155)$.

${ }^{42}$ Cfr. IMÍZCOZ BEÚNZA, Teresa: La teoría poética de Miguel de Unamuno, Pamplona, EUNSA, 1996, pág. 213.

${ }^{43}$ Decía el poeta moguereño: "En literatura, además de la esencia de las cosas -de lo que suele llamarse fondo- y además de la forma, hay una esencia, un fondo de esa misma forma, que es, a mi modo de ver, uno de los más interesantes aspectos de la estética" (JIMÉNEZ, Juan Ramón: "Antonio Azorín por MARTíNEZ RUIZ, J.", Helios, VII, Madrid, 1903, reproducido en GULLÓN, R. (ed.): ob. cit., pág. 23).
} 
octosílabo, las distintas apreciaciones y utilización de los distintos tipos de rima, el gusto por figuras retóricas basadas en la repetición (anáforas, paralelismos, reduplicaciones), la presencia de un claro dialogismo en sus poesías y en sus prólogos como marca de su necesidad comunicativa, su gusto por desentrañar las palabras del español (modismos castellanos y juegos etimológicos), o -como se expuso más arriba- su predilección, tantas veces señalada, por la paradoja en tanto elemento despertador de la conciencia de sus lectores y por la metáfora. Todos estos factores constituyen también una panoplia que no debe ser desdeñada en el momento de valorar la poética unamuniana y exigen un estudio pormenorizado en otro lugar ${ }^{44}$. Baste aquí señalar la diferencia de planteamiento que Unamuno otorga al estilo frente a la forma poética, situando a cada uno en su nivel correspondiente.

Don Miguel de Unamuno ha sido, sin duda, una de las cumbres literarias del siglo recién concluido. Pero, como se ha podido comprobar al hilo de estas páginas, es preciso también dejar constancia de su ejercicio en cuanto teórico de la literatura o, con mayor exactitud, como persona que se adentró en el análisis de los elementos caracterizadores de su propia poética, en coincidencia o en abierta oposición a la de otros contemporáneos. No sólo para hacerla comprender a los demás, tanto a sus partidarios como a sus detractores, sino también, tal vez, para obligarse a la exactitud que exige la exposición escrita de los pensamientos y sentimientos particulares.

\footnotetext{
${ }^{44}$ Cfr. ROMERO LUQUE, Manuel: Poesía y visión poética en don Miguel de Unamuno, Sevilla, Padilla libros, 2000.
} 